\title{
Editorial \\ Microbial Diversity Associated with Photosynthetic Organisms
}

\author{
Zhun Li * and Song-Gun Kim *
}

Biological Resource Center/Korean Collection for Type Cultures (KCTC), Korea Research Institute of Bioscience and Biotechnology, Jeongeup 56212, Korea

* Correspondence: lizhun@kribb.re.kr (Z.L.); sgkim@kribb.re.kr (S.-G.K.)

check for

updates

Citation: Li, Z.; Kim, S.-G. Microbial

Diversity Associated with

Photosynthetic Organisms. Diversity

2022, 14, 140. https://doi.org/

$10.3390 / \mathrm{d} 14020140$

Received: 11 February 2022

Accepted: 15 February 2022

Published: 16 February 2022

Publisher's Note: MDPI stays neutral with regard to jurisdictional claims in published maps and institutional affiliations.

Copyright: (C) 2022 by the authors. Licensee MDPI, Basel, Switzerland. This article is an open access article distributed under the terms and conditions of the Creative Commons Attribution (CC BY) license (https:// creativecommons.org/licenses/by/ $4.0 /)$.
Photosynthetic organisms (e.g., algae and plants) can produce organic substances from inorganic nutrients based on energy harvested from light as the primary producers in both the aquatic and terrestrial ecosystems. Photosynthetic organism-associated microorganisms are referred to as the photosynthetic organism microbiome. Currently, bacterial communities together with other microbial inhabitants are regarded as an indispensable part of all of the photosynthetic organisms, because they play a crucial role in the growth, nutrient uptake, health and stress tolerance of photosynthetic organisms [1]. Therefore, microbial diversity associated with photosynthetic organisms is an area of recent research interest for microbiologists, ecologists, taxonomists, biotechnologists, phycologists and agriculturists [2,3]. For example, in the aquatic ecosystem, microorganisms play multiple important roles in algal growth and survival [2,4]; in the terrestrial ecosystem, microorganisms (e.g., heterotrophic bacteria) not only decompose plant and animal organic matter, but also promote plant growth by complex communication mechanisms and nutrient exchange $[5,6]$.

Algae is a large and diverse group of photosynthetic eukaryotic organisms, and have been widely recognized for their capacity to produce polysaccharides, lipids, pigments and other valuable compounds in significant amounts [7]. Algae are used for producing healthy food and food supplements, and as an ingredient in aquaculture, animal feed, and as soil biofertilizer $[8,9]$. The alga-associated microorganisms are a pivotal part of the alga holobiont and have a key role in modulating algal populations in nature [9]. Interactions between algae and bacteria are arguably the most important interspecies interaction in the environment.

Plant-associated microorganisms are a key determinant of plant health and productivity and have received substantial attention in recent years $[6,10,11]$. Bacterial communities together with other microbial inhabitants are an inevitable and abundant part of all plants. Especially in recent years, the identification and characterization of rhizobacteria in agricultural production is considered to be of great significance. In our Special Issue, Zapata et al. [12] isolated 58 rhizobacterial strains from the plant rhizosphere of cassava Manihot esculenta Crantz CIAT MCOL1734 variety subjected to water deprivation, and identified the bacteria belonged to 12 genera: Achromobacter, Acinetobacter, Aeromonas, Buttiauxella, Cronobacter, Klebsiella, Ochrobactrum, Pluralibacter, Pseudomonas, Rhizobium, Serratia, and Sphingomonas. The cassava roots constitute a great reservoir of potential Gram-negative rhizobacteria with remarkable biotechnological applications. These strains can be used for plant inoculation or development of bio-inoculants to improve the drought tolerance of plant crops under water-deficit conditions.

Microbial genome sequences have been a concern ever since the emergence of nextgenome sequencing. Jiang et al. [13] investigated the complete genome sequence of the type strain of a plant growth-promoting bacterium Jejubacter calystegiae $\mathrm{KSNA}^{\mathrm{T}}$ (accession number KCTC $72234^{\mathrm{T}}$ ) using two complementary sequencing platforms (Illumina HiSeq and PacBio RSII), and provided a framework for further genetic studies to better understand the mechanism of bacteria-mediated salt tolerance in plants. Functional annotation of the 
KSNA2 ${ }^{\mathrm{T}}$ genome revealed several genes involved in salt tolerance pathways, such as those encoding sodium transporters, potassium transporters, and osmoprotectant enzymes. The results of the plant growth-promoting bacteria-based experiments indicate that strain KSNA2 $2^{\mathrm{T}}$ could improve seed germination in saline conditions, demonstrating its potential for future applications in agriculture and providing valuable insights for studies of the mechanisms of salt tolerance in plants.

This Special Issue of Diversity aims to investigate the microbial diversity (e.g., bacteria and fungi) associated with photosynthetic organisms, and provides an opportunity to improve the current knowledge regarding microbial diversity. This Special Issue will be also a good platform to discuss new approaches for monitoring microbial diversity. Meanwhile, we suggest the authors could deposit the isolated microorganisms on the Korean Collection for Type Cultures (KCTC; https: / /kctc.kribb.re.kr) of the Korea Research Institute of Bioscience and Biotechnology (KRIBB), which is one of the largest biological resource centers in the world.

Author Contributions: Data compilation: Z.L. and S.-G.K.; manuscript writing: Z.L. and S.-G.K.; editing: Z.L. and S.-G.K. All authors have read and agreed to the published version of the manuscript.

Funding: This work was supported by the KRIBB Research Initiative Program (KGM5232221).

Conflicts of Interest: The authors declare no conflict of interest.

\section{References}

1. Compant, S.; Samad, A.; Faist, H.; Sessitsch, A. A review on the plant microbiome: Ecology, functions, and emerging trends in microbial application. J. Adv. Res. 2019, 19, 29-37. [CrossRef] [PubMed]

2. Amin, S.; Hmelo, L.R.; van Tol, H.M.; Durham, B.P.; Carlson, L.T.; Heal, K.R.; Morales, R.L.; Berthiaume, C.T.; Parker, M.S.; Djunaedi, B.; et al. Interaction and signalling between a cosmopolitan phytoplankton and associated bacteria. Nature 2015, 522, 98-101. [CrossRef] [PubMed]

3. Ramanan, R.; Kim, B.-H.; Cho, D.-H.; Oh, H.-M.; Kim, H.-S. Algae-bacteria interactions: Evolution, ecology and emerging applications. Biotechnol. Adv. 2016, 34, 14-29. [CrossRef] [PubMed]

4. Gonzalez, L.E.; Bashan, Y. Increased Growth of the Microalga Chlorella vulgaris when Coimmobilized and Cocultured in Alginate Beads with the Plant-Growth-Promoting Bacterium Azospirillum brasilense. Appl. Environ. Microbiol. 2000, 66, 1527-1531. [CrossRef] [PubMed]

5. Mendes, R.; Garbeva, P.; Raaijmakers, J.M. The rhizosphere microbiome: Significance of plant beneficial, plant pathogenic, and human pathogenic microorganisms. FEMS Microbiol. Rev. 2013, 37, 634-663. [CrossRef] [PubMed]

6. Turner, T.R.; James, E.K.; Poole, P.S. The plant microbiome. Genome Biol. 2013, 14, 209. [CrossRef] [PubMed]

7. Wijffels, R.H.; Barbosa, M.J.; Eppink, M.H.M. Microalgae for the production of bulk chemicals and biofuels. Biofuels Bioprod. Biorefining 2010, 4, 287-295. [CrossRef]

8. Sharma, N.K.; Tiwari, S.P.; Tripathi, K.; Rai, A.K. Sustainability and cyanobacteria (blue-green algae): Facts and challenges. J. Appl. Phycol. 2011, 23, 1059-1081. [CrossRef]

9. Lian, J.; Wijffels, R.H.; Smidt, H.; Sipkema, D. The effect of the algal microbiome on industrial production of microalgae. Microb. Biotechnol. 2018, 11, 806-818. [CrossRef] [PubMed]

10. Berendsen, R.L.; Pieterse, C.M.J.; Bakker, P.A.H.M. The rhizosphere microbiome and plant health. Trends Plant Sci. 2012, 17, 478-486. [CrossRef] [PubMed]

11. Lebeis, S.L.; Rott, M.; Dangl, J.L.; Schulze-Lefert, P. Culturing a plant microbiome community at the cross-Rhodes. New Phytol. 2012, 196, 341-344. [CrossRef] [PubMed]

12. Zapata, T.; Galindo, D.M.; Corrales-Ducuara, A.R.; Ocampo-Ibáñez, I.D. The Diversity of Culture-Dependent Gram-Negative Rhizobacteria Associated with Manihot esculenta Crantz Plants Subjected to Water-Deficit Stress. Diversity 2021, 13, 366. [CrossRef]

13. Jiang, L.M.; Lee, Y.J.; Le Han, H.; Lee, M.H.; Jeong, J.C.; Kim, C.Y.; Kim, S.W.; Lee, J.Y. Genome Insights into the Novel Species Jejubacter calystegiae, a Plant Growth-Promoting Bacterium in Saline Conditions. Diversity 2021, 13, 24. [CrossRef] 